\title{
APRESENTAÇÃO
}

\section{Dossiê - Cartas a Karl Marx}

Há aproximadamente treze anos atrás o programa Radio 4, da emissora britânica BBC, realizou um concurso entre seus ouvintes para eleger quem eles consideravam o filósofo mais importante da história. Com larga vantagem sobre seus concorrentes Marx foi o escolhido pelos ouvintes britânicos, enfrentando outros nomes de peso da filosofia mundial que foram apoiados por jornais como The Guardian e The Independent, e pela revista The Economist.

Isso ocorrera antes mesmo da crise de 2008, que ressaltou ainda mais os graves problemas do capitalismo contemporâneo. As transformações gestadas pelo neoliberalismo desde, pelo menos, a década de 1970, resultaram em um interesse renovado pelas ideias de Marx em um público mais amplo que o usual. A precarização cada vez maior do trabalho e da vida, no centro do capitalismo mundial, demandava respostas mais profundas do que aquelas oferecidas pelas reflexões prevalecentes. À época, tornou-se famosa a questão da Rainha Elizabeth, aos professores da London School of Economics, sobre a emergência daquela que foi uma das maiores crises da história do capitalismo mundial: "se essas coisas foram tão grandes" - perguntou a Rainha - "como ninguém as notou?" A reação dos professores da LSE revelava a grande dificuldade que os setores hegemônicos da academia tinham para refletir sobre o capitalismo de seu tempo: admitiram na ocasião que estiveram envoltos em uma "política de negação" e que não se atentaram para os "riscos sistêmicos". Frente ao Senado estadunidense, por outro lado, Alan Greenspan, presidente do Federal Reserve por 18 anos, reconheceu que a crise expôs uma falha na ideologia de livre mercado que o havia guiado até então.

Se o mainstream acadêmico mostrava-se confuso diante dos acontecimentos, a reflexão marxista acumulava, a partir de diversas leituras diferentes, reflexões sobre a crise e as contradições do 
capitalismo. Ao lado e mais importante que o aumento do interesse pelas obras de Marx, foi o surgimento de movimentos de massa em resposta aos efeitos diversos da crise global de 2008. As resistências em diversos pontos do mundo - da Tunísia aos Estados Unidos - questionaram a ordem estabelecida. Ainda que as perspectivas ideológicas tenham sido diversas e os resultados políticos, até aqui, nem sempre animadores, esses movimentos de contestação evidenciaram que o consenso neoliberal dos anos 1990 estava longe de consolidado e que, menos ainda, seria ele o responsável por qualquer perspectiva de uma vida melhor para os $99 \%$ da população, como se tornou conhecida a caracterização dos movimentos contestatórios à época. De forma marginal ou como uma de suas referências centrais, o nome de Marx esteve associado a muitas dessas iniciativas em todo o mundo.

Novas publicações, organizações e conferências emergiram e tomaram corpo desde então. Jovens ativistas apresentaram suas demandas e antigas lideranças buscam, não sem problemas, conflitos e contradições, uma renovação que possa dialogar com elas. $\mathrm{Na}$ maior potência capitalista do mundo, antes centro da propaganda anticomunista, um número cada vez maior de jovens mostra-se aberto ao socialismo e localiza no capitalismo o cerne das crises no meio ambiente, no trabalho e nos serviços públicos.

É evidente, entretanto, que essas novas perspectivas colocamse ao lado de um recrudescimento da extrema-direita mundial. Mobilizando ressentimentos calcados em uma deterioração das condições de trabalho e de vida, cresce um nacionalismo xenofóbico nos países centrais, junto com os candidatos e governos que os representam. O nome de Marx aparece como um dos principais a ser combatido - muitas vezes de forma paranoica e tendo pouca ou quase nenhuma ligação com os principais alvos políticos desses grupos de extrema-direita. No caso mais emblemático até aqui, o norueguês Anders Behring Breivik assassinou, em 2011, 77 pessoas e feriu outras 51, a maioria jovens, combatendo o que chamava, em consonância com boa parte da extrema-direita mundial, de "marxismo cultural". 
Na América Latina, os governos progressistas das últimas duas décadas também vêm sendo atacados e combatidos como portadores de ideários comunistas e/ou marxistas por parte de grupos conservadores locais, independentemente do quão próximos ou distantes estejam das ideias de Marx. Com programas políticos de esquerda e centroesquerda, tais governos puderam conceder importantes reformas e avanços sociais para a população pobre dos países periféricos, além de terem aberto espaço para classes e grupos subalternos que estavam alijados da esfera pública. Mas, fizeram isso sem atacar as contradições do capitalismo e do Estado e a partir de um desenvolvimento econômico que se mostrou fraco com o tempo ao se fundamentar na exportação de commodities e no fortalecimento do consumo interno.

No Brasil, a crise dos governos do Partido dos Trabalhadores é associada ao nome de Marx por uma extrema-direita (de tipo) macarthista, não obstante o quão distantes do marxismo esses governos estiveram e o quanto apostaram em uma conciliação de classes que buscava fortalecer a burguesia local. Uma forte crise política e econômica se constituiu a partir das atuações de uma oposição irresponsável, de partes do judiciário, da grande mídia, da burguesia interna e internacional, abrindo caminho para um ultraliberalismo que flerta abertamente com os períodos mais macabros do país. O próprio Partido dos Trabalhadores tem a sua parcela de responsabilidade por, durante seus governos, ter se aliado a partidos de direita, alguns ligados inclusive ao conservadorismo evangélico, que hoje afirma ser o PT um emissário do diabo. Pior ainda, a violência contra a esquerda como um todo se manifesta nas ruas pelas mãos do chamado "cidadão de bem".

O marxismo, entretanto, sempre em uma crise e um ressurgimento renovado, atravessou períodos mais difíceis que aquele que se apresenta até aqui. A despeito das mazelas e do horror do dogmatismo stalinista, esteve voltado para um processo de autorreflexão mobilizado para a compreensão e transformação emancipatória da sociedade. A começar pelo próprio Marx - que 
escreveu que as revoluções proletárias "estão em constante autocrítica", "que zombam de modo cruel e minucioso de todas as meias medidas, das debilidades e dos aspectos deploráveis das suas primeiras tentativas"1 -, a necessidade de se repensar e desenvolver criticamente o arsenal teórico marxista para o diagnóstico dos conflitos existentes acompanharam o trabalho das reflexões clássicas e contemporâneas.

Atualmente, a pesquisa sobre a história intelectual do pensamento marxiano segue revelando essa capacidade crítica e autocrítica de Marx. Por outro lado, as novas demandas relacionadas às políticas identitárias possibilitaram o reflorescimento da vanguarda do pensamento político marxista, manifestado no debate da interconexão entre as questões de classe, gênero/sexualidade e raça, junto a um resgate e aprofundamento dos problemas em torno do meio ambiente e da ecologia, além da constante reavaliação das experiências soviéticas e do movimento dos trabalhadores como um todo.

É nesse espírito que a presente edição dos Cadernos Cemarx propôs a intelectuais/militantes contribuições em comemoração aos 200 anos de Marx. E o fizemos propondo um formato diferente. Solicitamos aos/às autores/as para que contribuíssem escrevendo Cartas a Marx, dialogando diretamente com ele sobre os dilemas e reflexões que nos atormentam.

No período que segue, o pensamento marxista será objeto de perseguição por essa força de extrema-direita que só se sustenta inventando o inimigo político a ser eliminado. O crime do marxismo é dar respostas concretas às situações de vida das pessoas. É dar sentido a projetos individuais e coletivos. E isso é perigoso demais para o pensamento único. Esperamos que esse dossiê seja uma forma de resistência a esse processo.

Boa leitura!

Maíra Machado Bichir Mariana Shinohara Roncato Murillo van der Laan Rafael Toitio 